\title{
IDS wt Allele
}

National Cancer Institute

\section{Source}

National Cancer Institute. IDS wt Allele. NCI Thesaurus. Code C75605.

Human IDS wild-type allele is located in the vicinity of Xq28 and is approximately $27 \mathrm{~kb}$ in length. This allele, which encodes iduronate 2 -sulfatase protein, plays a role in the mediation of proteoglycan turnover. Mutations in the gene that result in enzymatic deficiency of the gene product are associated with Mucopolysaccharidosis Type II (Hunter Syndrome). 